\title{
Comparing Between Commercial and Investment Banking: A Case Study from Iraq
}

\author{
Majeed Mohsen \\ South Technical University of Basra Iraq \\ Email: cleanclean170@gmail.com
}

Received: May 2, 2016; Accepted: September 16, 2016; Published: November 4, 2016 Permalink/DOI: http://dx.doi.org/10.17977/um002v8i22016p207

\begin{abstract}
The research aim is to evaluating investment and commercial banking to led the investor who want to be shareholder in equity to the suitable banking in Iraqi environment, which banking is suitable for risk averse and which is suitable for risk seeker, by comparing between depending on market attractiveness and business strength by comparing between Iraqi's investment and commercial banking for the period (2010-2014), it is evaluated market attractiveness by using banking return, banking risk, banking size, and banking stability and business strength by using market share (competition), and banking development. The data were from financial report used for statistical testing of difference between two means for comparing instead of comparing between variables directly by using t-test between means. The result explained there wasn't a difference between the two banking marketing, but commercial banking was more total risk than investment banking and systematic risk was the most in both banking. Research conclusion the risky environment, is resulting the conservative depositors decreasing the project, and weak effect of globalization on banking, that is resulting nearly same strategies to avoid internal risk by trying to create safely internal environment depending on strategy of less risk through minimizing unsystematic risks which reduce the ability on diversification which led to weak globalization's effect.
\end{abstract}

Keywords: Market Size, Market Share, Banking Development JEL Classification: G21, G24

\section{INTRODUCTION}

When there is different banking industries, there is different circumstances, then different challenges and opportunities, which characterize each industry, so these characteristics of the industry, are one of the important drivers of performance. The contribution in banks' shares, means that the shareholder shall bear the results of performance, because of that, the rational investor who want to contribute in shares of industry (banking) facing problem of choosing the suitable industry firstly according to his tendency to the risks, i.e. there is needing to Comparability between industries, to find which one is suitable to contribute in its banks' shares.

In Iraqi's banking industry, the investment banks dealing with the projects investing and accepting deposits, while commercial banks principally depends on the acceptance of deposits and employing funds, that means the nature of the risk varies between the two, if the level of risks had been known, the investor's tendency to the risks direct's the contributor towards the suitable industry, and appoint the level of the required return, so the rational behavior dep 
ends on the comparison to find if there are differences or similarities, and why? because rationality needs full picture to avoid capital losses and to keep the wealth.

To do Comparison between the two types of banking industry, there is needing to assess the strength of the industry has to be dealt with, the attractiveness of the market and the strength of the business, in the banking industry, return, risk, size, and financial stability important factors for achieving attractive market, business strength would need to study of the market structure and the banking development.

\section{LITERATURE REVIEW}

\section{Market Attractiveness}

Market attractiveness engaged with market's opportunities and challenges, this term is closely related to competence, American Marketing Association dictionary defines market attractiveness is "the degree of the market opportunities provided by market's segment and ability of company to meet competitive needs in that markets segment "that means ability of market to maximize the profit. Market attractiveness is correlated in a matrix of McKinsey \& Company (1970), according to the matrix market attractiveness consist of several factors such as actual return, Market size, annual market growth, competitiveness, environmental impact and so on.

Best (2005:506) explains Market attractiveness consist of three groups they are including market factors, competitive intensity, and market entry. Peng (2009:517) explained market attractiveness in four dimensions, they are market size and growth rate, competition, institutional contexts and cultural administrative, geographical and economic distance because of the nature of banking industry which deal with funds stages of input, process and output the researcher believes return, risk, size, and stability are essential factors in banking market attractiveness

\section{Market Return and Banking Return}

Market return refers to account mean of companies' returns in the market, it depends on actual returns of companies, in another word, the concept of profitability, so the research must explain profitability and its indicators. It means the ability to create profit depending on business activities, i.e.: the ability of given investments to earn a return from its use (Tulsian, 2014). Profitability reflect how management is using resources with efficiency to make profit, and then it is suitable indicator to measure financial efficiency because it measure Productivity of capital and operational processes, its consider "index of efficiency and guide to greater efficiency" (Olalekan \& Adeyinka, 2013) According to (Scott \& Arias, 2011) "Most of studies concern with bank profitability, including (Short,1979; Bourke, 1989; Molyneux \& Thomton, 1992; Goddard, Molyneux \& Wilson, 2004b), were depending on different linear Models to find various Factors which explain the profitability Banks profitability can be measure by return on assets (ROA) or return on equity (ROE), Also measured by net interest margin, (Dawood, 2014:1) explained that the most studies are used these indicators.(ROA) considers overall indicator for profitability because it is driven by the decisions of employing money and economic factors, and then represent bank's management ability to create return on its asset,"It allows for comparison between different companies or different sectors"(Ally, 2013:136), (Khrawish, 2011:19) explained that the (ROE) can be account by Net Income after tax dividing by the equity. Market return is referred 
to the average of returns of all firms existing in the market, it represents the return of all securities which are trading in financial market and used as a benchmark for comparing.

According to (Saksonova \& Solovjova, 2011) profitability one of the internal factors of financial performance but it does not reflect the whole picture because may be there is profitability but not create value, so it is important to look for drivers of creating value in shade of level of risks, (Violeta et al., 2010:297) stated. The drivers of creating values according to Applied Finance Group (AFG) are profitability, competition, growth, and cost of capital.

From the above concept of profitability, the researcher used (ROE) because the research engaged with shareholders depending on account mean of two banking (industries), while banking return represents the account mean of each industry of each industry.

\section{Risks}

Risks refer to the total risks which include systematic and unsystematic risks in another word it includes diversification and non-diversification risks. In Iraq there country risk is very high because of terrorism, also there is high management's risks, in this case, there is need to measure total risks. Though standard deviation is used to measure total risks, the coefficient of variation was used because of comparing between to different banking industries (commercial and investment).

\section{Banking Size}

In general banking, size refer to the number and power of investors in the market, in another word its reflect supply side in which companies can exist and build their position depending on its abilities, resources, and social correspondence. When banking market size is big to reflect more diversification and ability to absorb the loss, also more output. Dermine \& Schoenmaker (2010: 6) observed small banks need to large bailout when many banks face effect of correlated systematic risk, and capping size effect on reducing diversification of credit risks. There is high relationship between banking growth and banking size because big size means the ability to expand credits, result from high deposits which correlated with capital adequacy, and capital adequacy reflects solid capital to stay in bad probability, in other word there is a relationship between economic capital and size too.

Banking size can be measured by natural logarithm (Abuzar, 2013: 222240). The natural logarithm of total assets to natural logarithm of capital of banks, this indicator explains that the source of growth, either result from expanding in business or expanding in capital, while according to Beck and Kunt (2010:8) the size is measuring by dividing total banks assets to Gross Domestic production (GDP), the same indicator was used by (world Bank, 2005:1), Dermine \& Schoenmaker (2010: 2) explained that this indicator includes both risky and non risky assets, they used equity(book value) to GDP ratio" this ratio can be justified by the fact that, under Pillar 2 of the Basel 2 capital regulation". This indicator reflects elasticity needed for stability, so the researcher adopts this indicator agree with the case of Iraq because of the nature of the total risks which need to adjust capital adequacy, that means. it agrees with adjusted discount rate for measuring required return. 
To go "beyond size" there is need to measure efficiency and adequacy ratio, (Loukoianova, 2008) used non-parametric approach to measure efficiency by data envelopment analysis (DEA) depending on analyzing banks' cost and revenue (Loukoianova, 2008:4), non-parametric related to (distributed-free) while size, ratios are considered parametric data, so the research adopts indicator of (world bank, 2005) for efficiency by using Competitiveness indicator which agrees with question: How size of market is? and what is its structure?

\section{Banking Stability}

Banking stability refers to financial solidity and ability of banking sector to stay in financial safety, the ability measured by capital adequacy, (world bank, 2005:1), (GA. Holton 2003; Manganelli \& Engle, 2001) have used (VaR) Value at Risk (Aragonés et al. 2001) used Stress Test, others have used (Altman, 1983) model: (Loukoianova, 2008: 20), used Z-index to estimate banks probability failer, (Köhler, 2012:6) refers to the same indicator z-score, and mentioned several authors used z-score, (Foos et al. 2010), (Altunbas et al., 2009). The research used z- score because of the high risk environment in Iraq, and then it is important to go more than solvency when environment includes the high probability of financial shock (prices of goods and services, interest rate, and foreign exchange rate), and high management risks specially high financial administrative corruption.

\section{Business Strength}

\section{Market Structure of Banking and Market Share}

Market structure refers to the distribution of companies according to the size, number and position in the market, that reflect the level of competition which takes different forms such as Monopolistic, Competition, Oligopoly, pure competition, complete competition and so on. These forms are depending on Market Concentration. If there are few numbers of banks, so the alliance is driving the banking industry, and then result in high performance and high profits because of non-competitive prices. If there are large number of banks, so the efficiency is driving the banking industry.

According to the two points of view (Concentration and efficiency), there are two Hypothesis:

1. Structure-Conduct-Performance Hypothesis by (Bain, 1951: 293-324) who assumes the Concentration led to high prices

2. The Traditional Efficiency Hypothesis by (Demsetz, 1973:1-9) who assumes the companies' efficiency led to different market share, and high efficiency led to high market share.

Market share refers to ability of getting resources, or ability to maximize the number of sales, in banking financing is more essential because of the natures of small capital relative to another factor of financing (high financial leverage), so employing resources depending in high degree on deposits, this fact makes Market share of deposits is suitable indicator.

\section{Banking Development}

Both Commercial banking and investment banking are competence in giving private credit, that result industry's growth and encourages on research and development in firms, because" Efficient allocation of credit to the private sector 
and potential businesses leads to an increase in industrial growth and in turn, boosts economic growth" (Adnan, 2011:4).

According to the ESCWA (2005:22), financial development reflects the improvement in efficiency in quantity and quality service. Adnan (2013:1) Banking development can be measured by Access (loan and deposit size), efficiency (profitability, competitiveness) stability (capital adequacy, asset quality, liquidity). Also there are several indicators to measure financial development through banking such as are deposits to GDP, private credit to GDP, Khalaf (2009) mentioned authors like (Demetriades \& Hussein, 1996; Ghali, 1999; ESCWA, 2005) used private credit to GDP indicator to measure development of banking system. to complete with banking stability.

\section{METHOD}

The Iraqi central bank's policy requires expansion in equities of Iraqi banks for the purpose of responding to the requirements of the Basel III to increase the capital adequacy of the Iraqi banks, for that investor who want to be shareholders faces a problem of choosing banking. commercial banking depending principally on accepting current deposits and employing funds, while investment banking deal with investment projects and accepting deposits, so the investor who wants to be shareholder in equity against the following questions: Is there a difference in industry strength? If there is the difference which is suitable to risk-averse? Which is suitable to risk seeker? if there isn't difference what are the reasons?

The research aim is to led the investor who wants to be shareholder in equity to the suitable banking in Iraqi environment, by comparing between Investment and commercial banking depending on market attractiveness (return, risk, size, stability) and business strength (market share and banking development) to:

1. find if there is difference between the two banking in industry strength

2. which banking is suitable for risk-averse and which is suitable for risk seeker

3. which kind of risks is the principal and what is the result?

According to the problem of research, the hypothesis is "There aren't significant differences of industry strength between commercial and investment"

This hypothesis divided into:

1. There isn't significant difference in mean of banking return between commercial banking and investment banking

2. commercial's total risk are more than investment's but both are equal to unsystematic risks.

3. There isn't significant difference in mean of industry size between commercial banking and investment banking.

4. There isn't significant difference in mean of stability between commercial banking and investment banking.

5. There isn't significant difference in mean of market share between commercial banking and investment banking.

6. There isn't significant difference in mean of banking development between commercial banking and investment banking. 


\section{Data collection and tools}

Data was collection Depending on annual financial reports of banks to the period (2010-2014). To fulfill research aims, the research depending on the following tools

\section{(1) Market return and banking return}

$\mathrm{ROE}=$ net profit/equity.

$\mathrm{N}$

Market ROE. $=\sum$ ROE AVRs. $/ \mathrm{N} \quad i=1,2,3,4,5,6, \ldots$ 12(banks) $\ldots$ for each group.(2)

$\mathrm{i}=1$

$\mathrm{n}$

ROE AVRs. $=\sum \mathrm{ROE} / \mathrm{n} \quad j=1,2,3,4,5, \quad$ (years)

$j=1$

$n$

Banking return $=\sum$ ROE AVRs. $/ \mathrm{N} \quad k=1,2,3,4,5,6, \ldots$ (banks)

$\mathrm{k}=1$

(2) Risk:

Total risks: $\delta=\sqrt{ } \Sigma\left(X-X^{-}\right)^{2} / n-1(B l u m a n, 2006: 127)$

$\mathrm{X}^{-}$banking return $=\sum \mathrm{ROE}$ (AVRs.) $/ 6$ (banks)

$\mathrm{X}^{-}$market return $=\operatorname{Market}(\mathrm{ROE})$ of two banking......(12banks)

Systematic risk $=\delta * \mathrm{Rx}, \mathrm{y}$

$\mathrm{Rx}, \mathrm{y}=$ correlation between $\mathrm{X}^{-}$(whole market) and $\mathrm{X}^{-}$of industry(ROE)

Unsystematic risk=total risk-systematic risk

(3) Banking size:

$\mathrm{BZ}=$ equity (book value of banking): GDP

(4) Banking market share:

Ms= sum deposits of banking/ sum deposits of whole market

(5) Banking stability:

$\mathrm{z}$-score $=($ ROA + Equity: assets $) / \mathrm{SD}$ ROA

$\mathrm{ROA}=$ net profit/total assets

(6) Banking development:

$\mathrm{BD}=$ sum cash credit/GDP

To achieve results the research compared between the means of the two banking during the period (2010-2014) the test concerning two means was used:

$\mathrm{F}=\mathrm{S} 1^{2 / \mathrm{S}} 2^{2}$ (for testing two variances if they equal or not)

Test value $=($ observed value-excepted value $) /$ standard error

The research used the following equal:

$\mathrm{t}=\left\{\left(\mathrm{x}^{-} 1-\mathrm{x}^{-} 2\right)-(M 1-M 2)\right\} /\left(\sqrt{ }\left\{\left[(\mathrm{n} 1-1) \mathrm{s}^{2} 1+(\mathrm{n} 2-1) \mathrm{s}^{2} 2\right] / \mathrm{n} 1+\mathrm{n} 2-2\right\} \sqrt{ }(1 / \mathrm{n} 1+1 / \mathrm{n} 2)\right) \ldots .(9)$

$\mathrm{x}^{-}=$mean, $\mathrm{n}=$ sample size, $\mathrm{s}^{2}=$ variance, $\mathrm{M} 1-\mathrm{M} 2$ equal zero when no difference between population means is hypothesized (Bluman,2006:449)

\section{Research sample}

Sample was (6) banks of investment (all investment banks which listed in Iraq securities commission except the Islamic banks) which are working as market maker dealing with investment projects and accepting deposits, also sample includes (6) private commercial banks which are dealing as with accepting current saving and time deposits to reuse them in their financial activities. 


\section{RESULT AND DISCUSSION \\ The Comparing Between Two Banking \\ Banking Return and Risk}

From the table, the variances of commercial and investment banking are equal to the population variance, so equal (9) was used to find the difference between the means of commercial and investment banking. King return were comparing by the following hypothesizes:

Ho: There isn't significant difference in means of banking return between commercial banking and investment banking

H1: There is significant difference in means of banking return between commercial banking and investment banking.

The result of statistics test was:

\begin{tabular}{llllll}
\hline indicators & $\mathbf{v}$ & Cal. t & Tab. t & Sig. & Accepted hypo \\
\hline Banking return & 8 & 0.0951 & 1.860 & $5 \%$ & $\mathrm{Ho}=x^{-} l=x^{-} 2$
\end{tabular}

From the above, there isn't significant difference in banking return between the two banking. The above results is proving the first hypothesis

\section{Risk}

As shown in the table (5), Commercial banking is more total risk than investment but both are against the same (nearly)systematic risk. The table had shown the Unsystematic risk is equal to zero.

The results is proving the second hypothesis

\section{Banking Size}

Insert table (6)

Ho: There isn't significant difference in the mean of banking size between commercial banking and investment

$\mathrm{H1}$ : There is significant difference in the mean of banking size between commercial banking and investment

The result of statistics test was:

\begin{tabular}{llllll}
\hline indicators & $\mathbf{v}$ & Cal. t & Tab. t & Sig. & Accepted hypo \\
\hline BZ & 8 & 1.440 & 1.860 & $5 \%$ & Ho $=x^{-} l=x^{-} 2$
\end{tabular}

From the above results Null hypothesis accepted because cal. $t$ is less than tab. $t$, that means there isn't a significant difference between size's mean of two banking markets. The above results is proving the second hypothesis

\section{Banking Stability}

insert tables $(13,16)$

Ho: There isn't significant difference in mean of banking stability between commercial banking and investment banking

H1: There is significant difference in mean of banking stability between commercial banking and investment banking

The result of statistics' test was:

\begin{tabular}{llllll}
\hline indicators & $\mathbf{v}$ & Cal. t & Tab. t & Sig. & Accepted hypo \\
z-score & 8 & 1.549 & 1.860 & $5 \%$ & $\mathrm{Ho}=x^{-} l=x^{-} 2$
\end{tabular}


Null hypothesis was accepted because of cal. $t$ is less than tab. $t$, that means there isn't a significant difference between z-score means of two banking markets. The above results is proving the third hypothesis

\section{Banking Market Share}

Insert tables (7 and 8)

Ho: There is n't significant difference in mean of Ms between commercial banking and investment banking

H1: There is significant difference in mean of Ms between commercial banking and investment banking

The result of statistics test was:

\begin{tabular}{llllll}
\hline indicators & $\mathbf{v}$ & Cal. t & Tab. t & Sig. & Accepted hypo \\
\hline $\mathrm{Ms}$ & 8 & 1.039 & 1.860 & $5 \%$ & $\mathrm{Ho}=x^{-} l=x^{-} 2$
\end{tabular}

The null hypothesis was accepted because of cal. $t$ is less than tab. $t$, that means there isn't significant difference between Ms means of two banking groups. The above results is proving the third hypothesis

\section{Banking Development}

Insert tables (9 and 10)

Ho: There isn't significant difference in mean of BD between commercial banking and investment banking

$\mathrm{H} 1$ : There is significant difference in mean of BD between commercial banking and investment banking

The result of statistics' test was:

\begin{tabular}{llllll}
\hline indicators & $\mathbf{v}$ & Cal.t & Tab.t & Sig. & Accepted hypo \\
\hline $\mathrm{BD}$ & 8 & 1.468 & 1.860 & $5 \%$ & $\mathrm{Ho}=x^{-} 1=x^{-} 2$ \\
\hline
\end{tabular}

Null hypothesis was accepted because cal. $t$ is less than tab. $t$, that means there isn't significant difference between BD means of two banking markets. The above results is proving the third hypothesis

\section{CONCLUSION}

In order to analysis results in complete picture, they need long term and short term perspective, in short term perspective: when reviewing the last year of study (2015) there is some differences related to ability of commercial banking in employing its funds in cash credit more than investment banking, and then ability on developing other sectors by offering debits, this was resulting more profitability and more market attractiveness though its market size was less, in another word, effectiveness in using funds, but this situation was lead to more risk, and caused less stability. From another point of view, investment banking seems more conservative in using its funds in debits though it is bigger than commercial banking, that caused more stability and less risk but less ROE, this means, the investment banking did not utilize its banking size, so this situation makes it more adequacy than commercial banking because less contribution in developing other sector (through debits). 
According to above analysis, the investors either risky averse so they choose investment banking or risky seeker to choose commercial banking. Also, investment banking market share is more than commercial banking, that means the depositors attitudes are conservative due to the Iraqi environment which suffered from war. Results of the comparing show Why there isn't difference? There isn't difference between two banking in long range, because of the conservative depositors and few projects due to nature of Iraqi environment in shade of war, (the principal variable who dominating on Iraqi environment) pushing banking to the adapting with environment by strategy of reducing risk, especially depending on banking services, and exchange rates (UA\$ exchange rate), also high risky environment (country risks)is resulting from the weak contact with foreign markets, that refers to weak effect of globalization on banking system. The systematic risks represent the domination factor, and banks avoid high risks environment by trying to create safety internal environment by depending on techniques of less risky (defense strategy), this situation refers to weakdiversification in Iraqi banking system that means.

Commercial banks need to develop their market attractiveness by increasing size from absorbing more deposits, but this needs to more adequacy to get more stability. Investment banking need to increase its banking development by utilizing funds in more debts, especially it has a big market share and stability. Investment banking is suitable to risk-averse while commercial banking is suitable to risk seeker. The banking industry, need to reduce systematic risk by depending on high level of services' quality and looking for new markets.

\section{REFERENCES}

Abuzar, M.A. (2013). Internal and external determinants of profitability of Islamic banks in Sudan: evidence from panel data. Afro-Asian J. of Finance and accounting, 3(3), $222-240$.

Adnan, N. (2011). Measurement of Financial Development: A Fresh Approach. 8th International Conference on Islamic Economics and Finance, Center for Islamic Economics and Finance, Qatar Faculty of Islamic Studies.

Ally, Z. (2013). Comparative Analysis of Financial Performance of Commercial Banks in Tanzania. Research Journal of Finance and Accounting, 4(19) 133-143.

Altman, E. I. (1983). Bankruptcy Costs and the New Code. The Journal of Finance, 38(2), 517-522.

Altunbas, Y., Gambacorta, L., \& Marques, D. (2009). Securitization and the bank lending channel. European Economic Review, 53(8), 996-1009

America's Marketing Association (2013) Definition for market attractiveness factors.

Bain, J. (1951). Relation of Profit Rate to Industry Concentration. Quarterly Journal of Economics, 65(1), 293-324.

Best, R. J. (2005). Market-based Management: Strategies for Growing Customer Value and Profitability. 4th ed. Upper Saddle River, N.J.: Pearson-Prentice Hall.

Dawood, U. (2014). Factors Impacting Profitability of Commercial Banks in Pakistan for Period (2009) International Journal of scientific research publication, 4(3), 1-7. 
Demetriades, P., \& Hussein, K.A. (1996). Does Financial Development Cause Economic Growth? Time-Series Evidence From 16 Countries. Journal of Development Economics, 51(2), 387-411.

Demsetz, H. (1973). Industry Structure, Market Rivalry and Public Policy. Journal of Law and Economics, 16(1), 1-9.

Dermine, J., \& Schoenmaker, D. (2010). In Banking, Is Small Beautiful? Financial Markets, Institutions \& Instruments, 19, 1-19.

ESCWA (Economic and Social Commission for Western Asia). (2005). Economic Trends and Impacts: Banking Sector Lending Behavior and Efficiency in Selected ESCWA Member Countries, Issue No.3. United Nations, New York.

Foos, D., Norden L., \& Weber, M. (2010). Loan growth and riskiness of banks. Journal of banking and finance, 34, 2929-2940.

Ghali, K. (1999). Government Size and Economic Growth: Evidence from Multivariate Cointegration Analysis. Applied Economics, 31(8), 975-978.

Goddard, J., Molineux, P., \& Wilson, J. O.S. (2004). The Profitability of European Banks: A Cross-Sectional and Dinamic Panel Analysis. The Manchester School, 72(3), 363-381.

Khalaf, A. (2009). Study of commercial banking in Iraq: Past and present $\mathrm{PhD}$.Thesis/ University of Pune/India.

Khrawish, H.A. (2011). Determinants of Commercial Banks Performance: Evidence from Jordan. International Research Journal of Finance and Economics Zarqa University, 5(5), 19

Köhler, M. (2012). Which Bank Are More Risky? The Impact of Loan Growth and Business Model on Bank Risk-Taking, Deutsche. Discussion paper, No. 33, $1-53$.

Loukoianova, E. (2008). Analysis of the Efficiency and Profitability of the Japanese Banking System.IMF WP/08/63,p.4.

McKinsey \& Company. (1970). Enduring Ideas: The GE-McKinsey Nine Box Matrix. Retrieved from https://www.mckinsey.com.

Molyneux, P., \& Thornton, J. (1992). Determinants of European Bank Profitability: A Note. Journal of Banking and Finance, 16, 1173-1178.

Olalekan, A., \& Sokefun, A. (2013). Capital Adequacy and Banks Profitability: An Epirical Evidance From Nagiria. American Inernational Journal of Contemporary Research, 3(10), 87-93.

Peng, M.W. (2009). Global Strategy. 2nd ed. Cengage Learning, Canada, Nelson Education Ltd.

Saksonova, S., \& Solovjova, I. (2011). Analysis of the Quality and Profitability of Assets In The Banking System And The Impact of Macroeconomic Factors on Its Stability-Case of Latvia. International Conference on Applied Economics, (pp. 537-548).

Scott, J.W., \& Arias, J. C. (2011). Banking profitability Determinant. Business Intelligence Journal, 4(2), 209.

Tulsian, M. (2014). profitability analysis Acomparative Study of Sial \&TATA Stell. Jurnal of Economic and Finance, 3(19), 19-22.

Violeta, A., Oana, P., \& Eugenia, M. (2010). Modern Approaches Regarding the assessment of the Company's Overall Performance. Annals of Faculty of Economics, University of Oradea, Faculty of Economics, 1(1), 295-301. 